\title{
The Effect of Small Game Exercise on Freestyle Swimming Speed: A Case Study of Halu Oleo University Sport Science Student
}

\author{
Saifu', Manil Karakauki², Syed Kamaruzaman Syed Ali ${ }^{2}$, Aida Mustapha ${ }^{3}$, Budi Ariyanto Muslim ${ }^{4}$, \\ Faridah Ismiyati ${ }^{4}$, Cucu Sundara ${ }^{4}$, Sri Wahyuni ${ }^{4}$, Dwi Tiga Putri ${ }^{5}$, Agus Kristiyanto ${ }^{6}$, \\ Kukuh Wahyudin Pratama7 , Ahmad Nasrulloh ${ }^{8}$, Dewangga Yudhistira ${ }^{8, *}$ \\ ${ }^{1}$ Faculty of Teacher Training and Education, Halu Oleo University, Indonesia \\ ${ }^{2}$ Faculty of Education, University of Malaya, Malaysia \\ ${ }^{3}$ Faculty of Applied Science and Technology, Universiti Tun Hussein Onn Malaysia, Malaysia \\ ${ }^{4}$ Faculty of Sport Science, Jakarta State University, Indonesia \\ ${ }^{5}$ Faculty of Sport, Universitas Negeri Semarang, Indonesia \\ ${ }^{6}$ Faculty of Sports, Universitas Sebelas Maret, Indonesia \\ ${ }^{7}$ Institute of Advanced Science, Engineering, and Education (IASEE), Malaysia \\ ${ }^{8}$ Sport Science Faculty, Yogyakarta State University, Indonesia
}

Received March 4, 2021; Revised September 13, 2021; Accepted September 21, 2021

\section{Cite This Paper in the following Citation Styles}

(a): [1] Saifu, Manil Karakauki, Syed Kamaruzaman Syed Ali, Aida Mustapha, Budi Ariyanto Muslim, Faridah Ismiyati, Cucu Sundara, Sri Wahyuni, Dwi Tiga Putri, Agus Kristiyanto, Kukuh Wahyudin Pratama, Ahmad Nasrulloh, Dewangga Yudhistira, "The Effect of Small Game Exercise on Freestyle Swimming Speed: A Case Study of Halu Oleo University Sport Science Student," International Journal of Human Movement and Sports Sciences, Vol. 9, No. 6, pp. 1140 - 1145, 2021. DOI: 10.13189/saj.2021.090609.

(b): Saifu, Manil Karakauki, Syed Kamaruzaman Syed Ali, Aida Mustapha, Budi Ariyanto Muslim, Faridah Ismiyati, Cucu Sundara, Sri Wahyuni, Dwi Tiga Putri, Agus Kristiyanto, Kukuh Wahyudin Pratama, Ahmad Nasrulloh, Dewangga Yudhistira (2021). The Effect of Small Game Exercise on Freestyle Swimming Speed: A Case Study of Halu Oleo University Sport Science Student. International Journal of Human Movement and Sports Sciences, 9(6), 1140 1145. DOI: 10.13189/saj.2021.090609.

Copyright $\bigcirc 2021$ by authors, all rights reserved. Authors agree that this article remains permanently open access under the terms of the Creative Commons Attribution License 4.0 International License

\begin{abstract}
Mastering freestyle swimming focuses on increasing the swimming speed in order to complete the swimming distance in the shortest time. Because training for freestyle swimming must be carefully programmed and is progressive-based, this study is set to investigate the effect of small game exercises on freestyle swimming speed among the sport science student of Halu Oleo University. This study uses an experimental method with the one group pretest-posttest design. The population of this study consists of 10 students of Halu Oleo University Sport Science Student taken by simple random sampling. The instruments used were equipment for small games and exercises in the techniques of feet, hands, breath and freestyle swimming coordination. Samples of swimming exercises were speed records with a frequency of 3 times a week and carried out for 6 weeks. The results of the
\end{abstract}

normality and homogeneity test data analysis showed a significance value of $p>0.05$, which means that the data were normally distributed and homogeneous. $T$-test results showed a significance value of $p>0.05$ with a calculated $F$ value of 63.119 and an $\mathrm{F}$ table of 5.296, it can be concluded that there was a significant effect of small game training on the freestyle swimming speed for Sport Science Student of Halu Oleo University.

Keywords Freestyle Swimming, Speed, Small Game

\section{Introduction}

Swimming is a water sport in the form of a competition 
or game in which the swimmer moves through the water without using any tools by lifting the body to the surface of the water [1], [2], [3], [12], [13]. The fact that swimming provides a new experience, gives a feeling of pleasure, competes in feeling continuous success, and determines the method that is adapted to internal and external conditions [5], [6], [7]. This is reinforced by the literature that swimming can train muscles, work the lungs, train buoyancy and reduce tension on the body [4], [26], [27]. Previous research explained that swimming combines several components such as correct technique and skill, strength, coordination, power, and speed [14], [15], [16], [17]. In addition, scientific evidence was found that the intervention of a programmed swimming program for 10 weeks in adolescents with cerebral palsy gave improvement in walking ability without any adverse effects on pain and fatigue [18]. There are various styles in swimming, one of which is the freestyle. Freestyle is a style with the chest position facing the surface of the water, both hands are alternately moved far forward by pedaling, while both legs are swung up and down up and down, breathing is done when the arms are moved out of the water, when the body becomes tilted and the head turns to the side [8]. It takes patience to practice freestyle swimming, besides that you must pay attention to things such as motivation, frequency and pedaling strength [9]. If you want to win the match, swimmers must be able to complete the distance in the fastest time. Therefore, one of the most important predictors in winning a swimming race is speed. The literature explains that swimming competitions require good endurance and speed as well as technique in starting, turn and finish the match [19].

Based on participatory observation and field testing, Researchers see that the previously applied training method has not shown an optimal increase in terms of freestyle swimming speed, The literature explains that to increase speed in swimming, you must go through training and coaching in a programmed, systematic and progressive manner [13]. One training method that can increase freestyle speed is through small game exercises.

The literature explains that the small games method is a popular method [20], [28], [29]. This method refers directly to the game application process so that participants are more free and eager to achieve automation and speed movement [20]. In line with Hartati's research, he explained that the small games intervention was able to influence the collaboration of students in studying physical education and health [21]. In addition, the small games method does not have standard rules, this exercise is a technique for training the legs, arms, breathing and coordination, all of which are carried out in the water. Components of swimming training using this small game include speed training with the method of students running after other students in the water so that students have the ability to chase and avoid, this indirectly trains the speed of movement of the students' hands and feet, then students swim as fast as possible to catch the target in order to practice breathing in the water [10], [11].

Based on the description that has been presented, shows that the importance of providing varied training methods to increase speed in swimming. How can efforts be used to increase speed in swimming, especially freestyle Therefore, the author will experiment to test the small games method in the hope that this method can increase swimming speed, especially freestyle.

\section{Materials and Methods}

This type of research is an experiment with the one group pretest-posttest design. Instruments used in small games include swimming pools, stopwatches, star flags, and time keeping instruments. Small games include exercises in leg, hand, breath and freestyle swimming coordination. Small game exercises are done with a frequency of three times a week and carried out for six weeks. The small game training components are described as follows.

\section{1. "Hitam Hijau" Small Side Games}

The little "hitam-hijau" (black-green) game consists of two teams facing each other. Rules of the game: The game consists of 2 teams namely "hitam" (black) team and "hijau" (green) team. Each team consists of 5 members and both have the same number of members, both teams face each other with a distance of approximately 3 or 4 steps of an adult's foot, the team called is the team that runs and the team that is not called out is the team that chases, each student only chases the student who becomes his partner (this is the reason why the number of each team member must be equal). The game starts when the teacher shouts the name of one team. If the teacher yells, "hitam" (black) then the black team must run and the greed team chases the partner in the black team. Vice versa, if the teacher yells "hijau" (green), then the green team must run as fast as possible to avoid catching students from the black team.

For shouting in the name of the team, the teacher can extend the initial syllable so that it sounds thrilling and confusing students (to increase concentration) because both team names have the same initial syllable. Students who catch students who are chased are entitled to a reward in the form of punishment for students who are caught. For instance: students who catch ask for a carrying student who is caught about 10 meters sling. Repeat this game 3 or 4 times.

But here the "hitam-hijau" (black-green) game that is applied to sport science student of Halu Oleo University is the implementation in the water. There are 10 students divided into 2 groups, each group consisting of 5 people. The two groups face each other approximately 3 to 4 steps 
of adults. The team that is called is the team that avoids by swimming with freestyle and the team that is not called out is the team that chases the opponent and must swim using freestyle. Each student only chases after the student who becomes his partner. The game began when researchers shouted the name of one of the teams. If the researchers shout "hitam" (black), then by swimming freestyle the black team must avoid to do freestyle swimming. Then, the "hijau" (green) team chases their partners in the black team, by swimming and vice versa.

\subsection{Swimming Competition with Target Variations}

The second small game approach is a swimming competition with a target. The tool used is a plastic ball. The first thing to do is to line up students by the pool. Students are lined up like people swimming, the edge of the pool is depicted as the initial start of the race. The rules of the game students who have been lined up are ordered to chase the target which is a plastic ball. The winner is the student who gets the ball the fastest. The purpose of this small game is intended for students to try to move (swim) so the students are accustomed to doing $50 \mathrm{~m}$ freestyle swimming.

\subsection{M Diving Competitions}

The last little game approach is a $15 \mathrm{~m}$ dive competition. In this experiment, students were lined up alongside the pool then the coach gave a signal to all students to get ready to dive as far as $15 \mathrm{~m}$ simultaneously. Students of the special sports class are the first to win. The purpose of this small game is for students in the sports class to have a good breath in the implementation of freestyle swimming and is very supportive for their breathing endurance. The population of this research is the sport science student of Halu Oleo University with a sample of 10 students taken by simple random sampling. Samples were carried out twice, namely before being given a small game training (pretest) and after being given a small game training (posttest). Pretest data is the speed of 50 meter freestyle swimming students before being given a small game practice.

Posttest data is the speed of 50 meter freestyle swimming students after being given a small game practice. The implementation procedure is that the test participants (pretest) swim using the freestyle to cover 50 meters. The time taken by the sample to do freestyle swimming with a distance of 50 meters is recorded as research data to be analyzed to answer the research hypothesis. Data were analyzed using the IBM SPSS 24 program. Data were performed normality test to determine whether the research data was normally distributed or not with the criteria of normally distributed data if the significance of $p>0.05$. Homogeneity test data is performed to see whether the data is homogeneous or not, then proceed with hypothesis testing using the $t$-test.

\section{Result and Discussion}

The data of this study are the results of measurements of the effect of training using a small game on swimming $50 \mathrm{~m}$ freestyle in among the sport science student of Halu Oleo University. Data measurements were carried out twice, namely the speed of a 50 meter freestyle swimming speed before being given a small game practice (pretest) and the speed of a 50 meter freestyle swimming speed after being given a small game practice (posttest). Pretest and posttest data are shown in Table 1 and Table 2 .

Table 1. Data on the Results of the Pretest and Posttest

\begin{tabular}{|c|c|c|c|}
\hline Sample & \multicolumn{2}{|c|}{ Freestyle Swimming Speed } & \multirow{2}{*}{ Explanation } \\
\hline & Pretest & Posttest & \\
\hline 1 & 36.10 & 35.09 & Increased \\
\hline 2 & 37.20 & 35.92 & Increased \\
\hline 3 & 37.53 & 35.45 & Increased \\
\hline 4 & 38.23 & 36.78 & Increased \\
\hline 5 & 38.90 & 36.47 & Increased \\
\hline 6 & 39.86 & 36.26 & Increased \\
\hline 7 & 39.12 & 36.94 & Increased \\
\hline 8 & 40.05 & 37.53 & Increased \\
\hline 9 & 41.63 & 38.36 & Increased \\
\hline 10 & 42.90 & 38.96 & Increased \\
\hline
\end{tabular}

Table 2. Average Pretest and Posttest Results

\begin{tabular}{|c|c|c|c|c|c|}
\hline Treatment & N & Mean & SD & $\begin{array}{c}\text { Worst } \\
\text { Score }\end{array}$ & $\begin{array}{c}\text { Best } \\
\text { Score }\end{array}$ \\
\hline Pretest & 10 & 39.15 & 1.954 & 42.90 & 36.10 \\
\hline Posttest & 10 & 36.78 & 1.165 & 38.96 & 35.09 \\
\hline
\end{tabular}

After the pre-test and then given treatment for 18 meetings and ending with the post-test, the data obtained from the ability of the beginning and end of freestyle swimming. The data obtained on the pre-test of freestyle swimming ability obtained an average speed of 39.15 with the best ability is 36.10 and the worst ability is 42.90 . Post-test data on the ability to swim $50 \mathrm{~m}$ freestyle after making a small game approach for 6 weeks with a frequency of 3 times a week was found to be an average of 36.78 , with the best ability of 35.09 seconds and the worst ability of 38.96. This shows the influence of exercise using small games on $50 \mathrm{~m}$ freestyle swimming among sports science student of Halu Oleo University.

The frequency distribution of the sample before a small game exercise is done and after a small game training exercise on the 50 meter freestyle swimming speed is shown in Table 3. 
Table 3. Distribution of Students' Abilities Before and After Training

\begin{tabular}{|c|c|c|c|c|}
\hline Criteria & $\begin{array}{c}\text { Pretest } \\
\text { Freq. }\end{array}$ & $\%$ & $\begin{array}{c}\text { Posttest } \\
\text { Freq. }\end{array}$ & $\%$ \\
\hline $35-35.99$ & 0 & 0 & 3 & 30 \\
\hline $36-37.99$ & 1 & 10 & 4 & 40 \\
\hline $37-37.99$ & 2 & 20 & 1 & 10 \\
\hline $38-38.99$ & 2 & 20 & 2 & 20 \\
\hline $39-39.99$ & 2 & 20 & 0 & 0 \\
\hline $40-40.99$ & 1 & 10 & 0 & 0 \\
\hline $41-41.99$ & 1 & 10 & 0 & 0 \\
\hline $42-42.99$ & 1 & 10 & 0 & 0 \\
\hline Total & 10 & 100 & 10 & 100 \\
\hline
\end{tabular}

Based on the table above it is known that students with a $50 \mathrm{~m}$ freestyle swimming speed classification before treatment on the criteria as follows:
- 35 - 35.99: 0 people $(0 \%)$
- 36 - 36.99: 1 people $(10 \%)$
- $\quad 37$ - 37.99: 2 people $(20 \%)$
- 38 - 38.99: 2 people $(20 \%)$
- $\quad 39$ - 39.99: 2 people $(20 \%)$
- 40 - 40.99: 1 person $(10 \%)$
- $41-41,99: 1$ person $(10 \%)$
- 42 - 42.99: 1 person $(10 \%)$

Whereas after treatment of swimming speed $50 \mathrm{~m}$ freestyle on the criteria as follows
- 35 - 35.99: 3 people $(30 \%)$
- $\quad 36-36.99: 4$ people $(40 \%)$
- 37 - 37.99: 1 person $(10 \%)$
- $\quad 38$ - 38.99: 2 people $(20 \%)$
- 39 - 39.99: 0 people $(0 \%)$
- 40 - 40.99: 0 people $(10 \%)$
- $41-41.99: 0$ people $(0 \%)$
- 42 - 42.99: 0 people $(0 \%)$

This shows the influence of exercise using small games on $50 \mathrm{~m}$ freestyle swimming in sports science students of Halu Oleo University. The data was then analyzed using SPSS IBM 24. Normality test analysis results are shown in Table 4.

Table 4. Normality Test Results

\begin{tabular}{|c|c|c|}
\hline Treatment & Significance Value & Explanation \\
\hline Pretest & 0.950 & Normal \\
\hline Posttest & 0.769 & Normal \\
\hline
\end{tabular}

The table shows that the results of the calculation of the normality of the freestyle swimming speed data at the pretest obtained a significance value of 0.950 and at the posttest obtained a significance value of 0.769 . Because the results of the freestyle swimming speed normality data results obtained significance values greater than 0.05 ( $p>$ $0.05)$, it can be stated that the freestyle swimming speed data is normally distributed. This means that the distribution of data in this study meets the criteria for data normality curves as a condition of parametric statistical analysis. Then the data continued with the homogeneity test shown in Table 5.

Table 5. Homogeneity Test Results for Swimming Speed

\begin{tabular}{|c|c|c|}
\hline Treatment & $\boldsymbol{p}$ & Explanation \\
\cline { 1 - 2 } Pretest & \multirow{2}{*}{0.841} & Homogeneous \\
\hline Posttest & & \\
\hline
\end{tabular}

Homogeneity test results to test the similarity of the variance measurement results of the effect of small game exercises on $50 \mathrm{~m}$ freestyle swimming at the pretest and posttest significance value of 0.841. Because the significance value is greater than $0.05(p>0.05)$, it can be stated that the freestyle swimming speed measured by the pretest and posttest is homogeneous. This means that there is a similarity in variance between the swimming speed data measurement results at the time of the pretest and posttest so that the data meet the requirements for parametric statistical analysis. Then the parametric test $t$-test of the data is displayed in Table

Table 6. T-Test Results for Swimming Speed

\begin{tabular}{|c|c|c|c|c|}
\hline Test & $\boldsymbol{t}$-value & $\boldsymbol{t}$ table & $\boldsymbol{p}$ & Explanation \\
\hline Pretest & 63.119 & 5.296 & 0.005 & Significant \\
\hline
\end{tabular}

Based on the results of the t-test analysis, the t-count value was 63,119, while the t-table was 5.296 with a significance value of 0.005 . Because the significance value of $p>0.05$, it can be said that there is a significant difference in swimming speed at the pretest and posttest. In addition, because the value of $t$ arithmetic $>t$ table, it can be concluded that there is a significant effect between training using small games on 50m freestyle swimming in sports science students at Halu Oleo University, so that the research hypothesis is accepted. Small games are all forms of games that do not have standard rules in their application both regarding the rules of the game, the equipment used, the size of the field, and the duration of the game. Small games can be adapted to the circumstances or situations where and when the games in question are held. By exercising using small games, the researchers tried to arouse the motivation of sports science students at Halu Oleo University to determine the effect of 50 meters freestyle swimming using small game exercises, like a "Hitam- hijau" (black-green) game, a swimming competition with a variety of targets, and a diving competition as far as 15 meters.

Small games are complex games that involve cognitive, affective, and psychomotor abilities, but in practice these small games are packaged in a way that students feel like playing, so that these exercises do not burden students. In order for someone to be able to do freestyle well, they must pay attention to the things that must be considered in freestyle swimming. Among others, namely, achievement motivation, pedaling frequency, and power. Achievement 
motivation is an encouragement that is contained in a person to always try to improve abilities. Another dimension related to the 50 meter freestyle swimming is the frequency of pedaling, in the 50 meter freestyle swimming the number of pedaling frequencies will greatly affect the travel time. In addition to motivating pedaling achievement, one of the important efforts that must be made to influence the 50-meter freestyle swimming is how much force the Halu Oleo University sports science students exert during the 50-meter freestyle swimming arm strength..

Scientific evidence explains that although small games are games, they are able to develop physical endurance in sports performance [22], [23], [25]. This is in accordance with a study from Radziminski et al. (2013) which explained that there was a significant increase in physical terms, especially endurance which was carried out for 8 weeks [24]. In this study, it has been proven that there is a significant effect of small game training on the speed of 50 meters freestyle swimming in sports science students at Halu Oleo University.

\section{Conclusions}

Swimming is a sport that is carried out in water with an effort to lift his body to float to be able to breathe, move back and forth for health, therapeutic, recreational, educational purposes, to be the basis of other water sports, to gain achievements by programmed, planned and progressive exercises. Freestyle swimming is swimming with the chest facing the surface of the water, both hands are alternately moved far forward with a pedaling motion, while both legs are whipped up and down up-down, breathing is done when the arms are moved out of the water, when the body it tilts and the head looks sideways. One of the swimming exercises is a small game exercise. From the data analysis and hypothesis testing, it can be concluded that there is a significant influence of the practice of using small games on the $50 \mathrm{~m}$ freestyle swimming speed among sport science student of Halu Oleo University.

\section{Acknowledgement}

This research is supported by Halu Oleo University, Institute of Advanced Science, Engineering, and Education (IASEE) Malaysia and Jakarta State University.

\section{REFERENCES}

[1] M. Alkatan, D. R. Machin, J. R. Baker, A. S. Akkari, W. Park, and H. Tanaka, "Effects of Swimming and Cycling Exercise Intervention on Vascular Function in Patients with
Osteoarthritis," Am. J. Cardiol., vol. 117, no. 1, pp. 141145, 2016, doi: 10.1016/j.amjcard.2015.10.017.

[2] X. M. Li, J. M. Yuan, S. J. Fu, and Y. G. Zhang, "The effect of sustained swimming exercise on the growth performance, muscle cellularity and flesh quality of juvenile qingbo (Spinibarbus sinensis)," Aquaculture, vol. 465, pp. 287-295, 2016, doi: 10.1016/j.aquaculture.2016.09.021.

[3] I. Manna, K. Jana, and P. K. Samanta, "Intensive swimming exercise-induced oxidative stress and reproductive dysfunction in male wistar rats: Protective role of a-tocopherol succinate," Can. J. Appl. Physiol., vol. 29, no. 2, pp. 172-185, 2004, doi: 10.1139/h04-013.

[4] V. J. Clemente-Suárez, A. Dalamitros, J. Ribeiro, A. Sousa, R. J. Fernandes, and J. P. Vilas-Boas, "The effects of two different swimming training periodization on physiological parameters at various exercise intensities," Eur. J. Sport Sci., vol. 17, no. 4, pp. 425-432, 2017, doi: $10.1080 / 17461391.2016 .1253775$.

[5] W. Liu, X. Xue, J. Xia, J. Liu, and Z. Qi, "Swimming exercise reverses CUMS-induced changes in depression -like behaviors and hippocampal plasticity-related proteins," J. Affect. Disord., vol. 227, no. October, pp. 126-135, 2018, doi: 10.1016/j.jad.2017.10.019.

[6] P. Hojman, C. Dethlefsen, C. Brandt, J. Hansen, L. Pedersen, and B. K. Pedersen, "Exercise-induced muscle-derived cytokines inhibit mammary cancer cell growth," Am. J. Physiol. - Endocrinol. Metab., vol. 301, no. 3, pp. 504-510, 2011, doi: 10.1152/ajpendo.00520.2010.

[7] S. Verma, G. Novati, and P. Koumoutsakos, "Efficient collective swimming by harnessing vortices through deep reinforcement learning," Proc. Natl. Acad. Sci. U. S. A., vol. 115, no. 23, pp. 5849-5854, 2018, doi: 10.1073/pnas.1800923115.

[8] Z. B. AKTUG, R. IRI, and E. TOP, "The Investigation of the Relationship between Children's 50m Freestyle Swimming Performances and Motor Performances," Asian J. Educ. Train., vol. 4, no. 1, pp. 41-44, 2018, doi: 10.20448/journal.522.2018.41.41.44.

[9] F. Martinescu-Bădălan and R.-E. Herman, "Training Program for Military Students for the Improvement of the Freestyle Swimming Method," Int. Conf. KNOWLEDGE -BASED Organ., vol. 24, no. 2, pp. 324-330, 2018, doi: 10.1515/kbo-2018-0110.

[10] C. Nichols, A. Smith, S. Huelsman, C. Schemmel, J. C. Doll, and S. J. Jacquemin, "Preliminary understanding of complexities in swimming performance of common minnow (Cyprinidae) taxa," Ohio J. Sci., vol. 118, no. 2, pp. 16-24, 2018, doi: 10.18061/OJS.V118I2.6117.

[11] R. Afdhilla Nasution and P. Sukoco, "Developing Affective Instrument Based on Performance in Extracurricular Swimming," vol. 278, no. YISHPESS, pp. 141-143, 2019, doi: 10.2991/yishpess-cois-18.2018.36.

[12] M.C. Grant, "Land based resistance training and youth swimming performance," International Journal of Sports and Exercise Medicine, vol. 3, no 4, pp. 1-11, 2017, doi: $10.23937 / 2469-5718 / 1510064$.

[13] S. Subagyo, G. Guntur, A, Alim,"Swimming Crawl Style: The Effect of Pure or Progressive Method And Level of 
Body Fat,"Jurnal Cakrawala Pendidikan, vol. 39, no. 1, pp. 183-190, 2020.

[14] Z.B. Aktug, R. Iri, E. Top." The Investigation of the Relationship between Children's 50m Freestyle Swimming Performances and Motor Performances," Asian Journal of Education and Training, vol. 4, no. 1, pp. 41-44, 2018.

[15] N. Garido, D.A. Marinho, T.M. Barbosa, A.J. Silva, J.A. Perez-Turpin, M.C. Marques.” Relationships between dry land strength, power variables and short sprint performance in young competitive swimmers." Journal of Human Sport and Exercise, Vol. 2, pp. 240-249, 2010.

[16] P.G. Morouco, D.A. Marinho, N.M. Amaro, J.A. Perz-Turpin, \& M.C. Marques." Effects of dry-land strength training on swimming performance: a brief review." Journal Human Sport and Exercise, Vol. 7, no. 2, pp. 553-559, 2012.

[17] A. Yapici, B. Maden, G. Findikoglu." The effect of a 6-week land and resistance training of 13-16 years old swimmers groups to lower limb isokinetic strength values and to swimming performance 13-16 yaş grubu yüzücülerde 6 haftalık kara ve direnç antrenmanlarının alt ekstremite izokinetik kuvvet performansına ve yüzme derecelerine etkisi.”Journal of Human Sciences, Vol. 13, no. 3, pp. 5269-5281, 2016.

[18] M. Declerck, M. Verheul, D. Daly, \& R. Sanders.”Benefits and enjoyment of a swimming intervention for Youth with Cerebral Palsy: an RCT Study. "Pediatric physical therapy. Vol. 28, no. 2, pp. 162-169, 2016.

[19] P.P.Y. Wu, M. O'Shea, K. Mengersen, C. Drovandi, K.E. McGibbon, M. Osborne." Predicting performance in $4 \mathrm{x}$ 200-m freestyle swimming relay events."Plos one. Vol 16, no. 7 , pp. e0254538, 2021.

[20] S. Syahrastani, F. Kamal.” The influence of Drill, Small Game, And Agility Exercise Methods Against Dribbling Capability of Student At PSB Junior Footall School District XIII Koto Kampar.”Jurnal MenSana. Vol. 5, no. 1, pp. 40-45, 2020.

[21] S.C.Y. Hartati, A. Priambodo, A. Kristiyandaru." Permainan Kecil (Cara Efektif Mengembangkan Fisik, Motorik Keterampilan dan Emosional).” Malang Wineka Media, 2012.

[22] O. Faude, A. Steffen, M. Kellmann, T. Meyer. "The effect of short-term interval training during the competitive season on physical fitness and signs of fatigue: A crossover trial in high-level youth football players. "International Journal of Sports Physiology and Performance. Vol. 9, no. 6, pp. 936-944, 2014.

[23] A. Los Arcos, J.S. Vazquez, L. Martin, J. Lerga, F. Sanchez, F. Villagra, \& J.J. Zulueta". Effects of smallsided games vs interval training in aerobic fitness and physical enjoyment in young elite soccer players." PLoS ONE. Vol. 10, no. 9, pp. e0137224, 2015.

[24] L. Radziminski, P. Rompa, W. Barnat, R. Dargiewicz \& Z. Jastrzebski."A comparison of the physiological and technical effects of high-intensity running and small-sided games in young soccer players." International Journal of Sports Science and Coaching. Vol. 8, no. (3), pp. 455-465, 2013.

[25] E. Akdoğan, I. Yılmaz, Y. Köklü, U. Alemdaroğlu \& A.O Cerrah.'The Effect of Isolated or Combined Small-Sided Games And Speed Endurance Training on Physical Performance Parameters in Young Soccer Player." Kinesiology. Vol 5, no 1, pp. 78-85, 2021.

[26] Nasrulloh, A., Prasetyo, Y., Nugroho, S., Yuniana, R., Pratama, K. W., Mustapha, A., \& Idrus, S. Z. S. "Tricet Method to Increase the Hypertrophy Muscle." In Journal of Physics: Conference Series (Vol. 1529, No. 3, p. 032006). IOP Publishing. 2020.

[27] Nugroho, S., Nasrulloh, A., Karyono, T. H., Dwihandaka, R., \& Pratama, K. W. "Effect of intensity and interval levels of trapping circuit training on the physical condition of badminton players". Journal of Physical Education and Sport, 21, 1981-1987. 2021. DOI:10.7752/jpes.2021.s3252.

[28] Sutapa, P., Prasetyo, Y., Pratama, K. W., Karakauki, M., Mustapha, A., \& Idrus, S. Z. S. "Motor Development Index (MDI) Based on Combination of Human Development Index (HDI) and Sport Development Index (SDI) as a Success Parameter of Motor Development among Preschool Children: An Observational Study." In Journal of Physics: Conference Series (Vol. 1529, No. 3, p. 032003). IOP Publishing. 2020.

[29] Kristiyanto, A., Prasetyo, Y., Pratama, K. W., Karakauki, M., Mustapha, A., \& Idrus, S. Z. S. "Access to The Utilization of Science and Technology of Sports and Familiarity of the Sports Community towards Technologically Based Devices." In Journal of Physics: Conference Series (Vol. 1529, No. 2, p. 022099). IOP Publishing. 2020. 